\title{
Communication Strategies, Attitude, and Oral Output of EFL Learners: A Study of Relations
}

\author{
Mina Rastegar, Samira Sadat Mirzadi Gohari \\ Department of Foreign Languages, Shahid Bahonar University of Kerman, Kerman, Iran \\ Email: Rastegar@uk.ac.ir, Samiramirzadi@gmail.com
}

How to cite this paper: Rastegar, M., \& Gohari, S. S. M. (2016). Communication Strategies, Attitude, and Oral Output of EFL Learners: A Study of Relations. Open Journal of Modern Linguistics, 6, 401-419. http://dx.doi.org/10.4236/ojml.2016.65036

Received: February 6, 2016

Accepted: October 21, 2016

Published: October 25, 2016

Copyright $\odot 2016$ by authors and Scientific Research Publishing Inc. This work is licensed under the Creative Commons Attribution International License (CC BY 4.0).

http://creativecommons.org/licenses/by/4.0/

\begin{abstract}
The present study aimed at investigating the relationship among EFL learners' speaking strategies use, attitude, and English language oral output. The data was collected from 150 EFL language institute students regarding the relationship among their speaking strategies use, attitude, and English language oral output. To this end, three instruments of the Oral Communication Strategy Questionnaire (Nakatani, 2006), Attitude Scale (Rastegar, 2003), and Cambridge Preliminary English Test (PET), placement tool for language proficiency, were used. The results showed that there was a significant relationship between different subscales of communication strategies use and attitude of the intermediate Iranian EFL learners. Moreover, relationship between communication strategy use of EFL learners and their English language oral output was statistically significant. As a major conclusion, the importance of speaking strategy training in learner education with a regard to the learners' attitude towards language learning and their oral language output should not be ignored.
\end{abstract}

\section{Keywords}

Communication Strategies (CSs), Attitude, Oral Language Output

\section{Introduction}

Today, everybody needs to be able to communicate efficiently in English. As suggested by Canale and Swain (1980) and Canale (1983), this ability requires communicative competence which includes grammatical, sociolinguistic, discourse, and strategic competences. Among all, the one which holds the decisive role is recognized as strategic competence. According to Dörnyei and Thurrell (1991), the underdevelopment of strategic competence causes the lack of fluency and conversation skills about which many learners often complain. Strategic competence can be observed through the use of such Communication Strategies (CSs) as paraphrase, literal translation, language switch, ges- 
tures, and appealing for assistance through which the interlocutors can reach their goal of communication. Generally speaking, CSs have been defined as learners' efforts to maintain the conversation when facing difficulties (Corder, 1983; Dörnyei \& Scott, 1997); and/or to enhance the effectiveness of the conversation (Littlemore, 2003).

Attitudes are seen paramount in language growth or decay, restoration or destruction. They are internal states that affect what the learners are likely to do. The internal state is some degree of positive/negative or favorable/unfavorable reaction towards an object. Some learners may have negative attitude towards the second language and learn it in order to prevail over people in the community. Some may have positive attitude which strengthens the motivation, and some others might even generate neutral feelings. Baker (1992, p. 10) defines attitude as "a hypothetical construct used to explain the direction and persistence of human behavior". Attitudes towards language may have been developed by learners' experiences. It could refer to attitudes towards language learning as well as towards the members of a particular speech community. Fasold (1984) claimed that attitudes towards a language are often mirrored in the attitudes towards the members of that speech community. Brown (2000) uses the term "attitudes" to refer to the set of beliefs that the learner holds towards both members of the target language group and his own culture. Most of the previous studies (e.g., Ellis, 1985; Gardner, 1985; Gardner \& Lambert, 1972) conducted yet show that the learners with both positive and negative attitudes towards learning English might use CSs in different ways. Surely, the degree of success in acquiring a second or a foreign language is to a large extent determined by learners' individual differences in terms of their attitudes. This has remained as an established fact in applied linguistic research (Baker, 2001; Gardner, 2001; Gass \& Selinker, 2001). In spite of undeniably psychological phenomena, these differences cannot be explained on purely mental grounds.

Based on the differences in learners' attitudes towards learning English as a Foreign Language and the various use of CSs, their oral language output may differ among them. In the following sections, a general overview of these three factors and their relationship with each other are presented.

\section{Literature Review}

\subsection{Communication Strategies}

Using communication strategies in the foreign language classroom has been studied in such countries as the United States, Great Britain, and China since the 1980's and more recently in some Arab countries (Rababah, 2003; 2005). Since the notion of communication strategy was first introduced by Selinker (1972), several definitions of communication strategies have been proposed; however, he did not deal with communication strategies in detail. Tarone, Cohen and Dumas (1976) defined communication strategy as systematic attempt by the learner to express or decode meaning in the target language, in situations where the appropriate systematic target language rules have not been formed. Tarone (1980) stated that communication strategies are considered to be an interactional phenomenon; a mutual attempt of two interlocutors to agree on a 
meaning in situations where requisite meaning structures are not shared.

Communication strategies comprise a subset of language learning strategies, focusing on approaches for conveying meaningful information that is new to the recipient (Cohen, 1996). Second language speakers get help from communication strategies in order to handle communication breakdowns and to communicate more effectively (Dörnyei, 1995; Dörnyei \& Scott, 1997). There are two perspectives regarding the classifications of communication strategies; interactional and psycholinguistic views. In interactional view, "CSs are regarded not only as problem-solving phenomena to compensate for communication disruptions, but also as devices with pragmatic discourse functions for message enhancement" (Nakatani \& Gho, 2007: p. 208). The psycholinguistic view examines "learners' problem-solving behaviors arising from gaps in their lexical knowledge" (Nakatani \& Gho, 2007: p. 208).

For the past three decades, there have been a large number of studies conducted to examine the various aspects of CSs. Tarone (1980) defined CSs as "tools used in negotiation of meaning where both interlocutors are attempting to agree as to a communicative goal and a shared enterprise in which both the speaker and the hearer are involved rather than being only the responsibility of the speaker" (p. 424). Faerch and Kasper (1983a, p. 36) defined CSs in terms of "the individual's mental responses to a problem rather than as a joint response by two people, which means that CSs deal with language production problems that occur at the planning stage". Also, Dörnyei (1995) extended the definition of CSs believing that insufficient processing time is a big communication problem for L2 speakers and suggesting stalling strategies that help the speakers gain time to think and to keep the channel of communication open. To analyze learners' use of CS in both perspectives, Dörnyei (1995) proposed taxonomies consisting of the following major categories; Avoidance or Reduction Strategies, Achievement or Compensatory Strategies, and Stalling or Time-gaining Strategies.

Nakatani (2006), having the awareness of the deficiency in the field, developed Oral Communication Strategy Inventory (OCSI) on Japanese learners designed considering the communication problems encountered by the people learning EFL. Nakatani (2006) classified speaking strategies as social-affective, fluency-oriented, negotiation for meaning, accuracy-oriented, massage reduction and alteration, nonverbal strategies while speaking, massage abandonment, and attempt to think in English strategies. The OCSI (Nakatani, 2006) has been used to investigate CS use through several studies focusing on the differences in CS use between high and low proficiency groups, which found that high proficiency learners were more likely to use social-affective strategies (Nakatani, 2006; Chuanchaisit \& Prapphal, 2009), fluency-oriented strategies (Nakatani, 2006; Chuanchaisit \& Prapphal, 2009), negotiation for meaning whilst speaking strategies (Nakatani, 2006) and accuracy-oriented strategies. Additionally, studies suggested that low proficiency learners were more likely to use message abandonment strategies (Wannaruk, 2003; Nakatani, 2006) or topic avoidance strategies (Mei \& Nathalang, 2010). In general, the results of such studies indicated that high proficiency learners were more likely to make effective use of achievement strategies to enhance communi- 
cation; whereas, low proficiency learners were more likely to use reduction strategies.

With regard to language proficiency, Paribakht (1985) studied the relationship between strategic competence and language proficiency which suggested a directionality of transition in the learners' use of CS towards that of the native speakers, and that advanced learners were in the mid-position between native speakers and low proficient learners. Poulisse and Schils (1989) examined the effects of proficiency and task-related factors on the compensatory strategies used by Dutch learners of English. The results of their study revealed that the most advanced students used fewer compensatory strategies than did the least proficient ones. The subjects predominantly used analytic strategies in a picture naming/description task; however, they frequently adopted holistic strategies and transferred strategies in a story retell task and an oral interview. Rost and Ross' (1991) study also showed that the use of certain strategies was correlated with L2 proficiency. They claimed that proficiency is the weightiest predictor of strategy use. Besides, Zhang (2005) conducted a study on the use of CSs in dyad talks and the function of proficiency level in strategy selection by Taiwanese elementary school EFL learners. The results of this study showed that the four most frequently employed strategies were language switch, mime, appeal for assistance, and approximation. The more proficient learners were inclined to use L2-based strategies while the less proficient ones employed more L1-based strategies.

In terms of task type, Yarmohammadi and Seif (1992) found that Iranian EFL learners' preference for the use of achievement strategies had no significant relation to the task type; even though, the nature of the task might influence the type and proportion of some individual strategies used.

Moreover, Derwing and Rossiter (2002) investigated the perceptions of 100 adult ESL learners regarding their pronunciation difficulties and their strategies use facing with communication breakdown. They found that the most commonly used strategies were paraphrasing, self-repetition, writing/spelling, and volume adjustment when the participants had not been understood.

Using CS categories based on Tarone's (1981) and Faerch and Kasper's (1983b) taxonomies, the study by Prapobratanakul and Kangkun (2011) investigated the CS use of young Thai students. They found paralinguistic strategies (such as gestures or facial expressions) to be most frequently used (45\%) followed by intralinguistic strategies such as circumlocution and approximation (26\%).

Nakatani, Makki, and Bradley's (2012) study investigated the use of CSs in open-ended conversation tasks. The results showed that the frequency of CSs was relatively low. Indeed, no significant difference was found between the three groups vis-a-vis the total number of CSs used; however, it was found that elementary-level students frequently used the strategies which impeded the flow of their communication. On the other hand, advanced students mostly employed strategies to maintain the flow of interaction. Nevertheless, no group could adequately use self-solving strategies such as circumlocution and approximation for target language vocabularies. The results also indicated that while a small number of students could use CSs for conversation tasks, it was necessary 
to introduce explicit meta-cognitive strategy training to raise awareness of CS use in order to further expand target language development.

The results of another study done by Yarahmadzehi and Safarzade Samani (2014) identifying the CSs used by Iranian pre-intermediate EFL learners in oral communication revealed that the most frequently used strategies by the learners were use of fillers and hesitation devices, code switching, appeal for help, and self-repetition and the least frequently used strategies were word coinage, foreignizing, and comprehension check.

Additionally, the study done by Patil and Karekatti (2015) investigated the communication strategies used by engineering students in selected oral communicative situations. The analysis of the use of CSs showed that the subjects used more CSs in the task of interview than in public speech and presentation, and the most often used strategies in all the tasks were use of fillers, repetition, and restructuring. Moreover, the investigation on the relationship of critical thinking and oral communication strategy use among 71 Iranian students majoring English Translation and Literature conducted by Hosseini, Sarfallah, and Bakhshipour (2015) revealed that there was a significant relationship between the participants' critical thinking and their oral communication strategy, and also, the strategies for coping with speaking problems acted as the best predictor of learners' critical thinking.

\subsection{Attitude}

Primarily related to actual classroom learning situations, attitude is a very decisive and eminent contributing factor in the second/foreign language learning process. Attitudes are based upon experiences and closely related to our beliefs. Thus, the researchers believe that effective language teaching strategies can encourage students to hold more positive attitudes towards the learning process in general and learning EFL in particular. Some researchers (e.g., Stern, 1983: pp. 376-377) distinguish between the three types of attitudes in L2 situation; “(a) Attitudes towards the community and people who speak the L2 (group specific attitudes), (b) Attitudes towards learning the language concerned, and (c) Attitudes towards languages and language learning in general". These attitudes may be influenced by the type of the learner's personality; for example, being as "ethnocentric" or "authoritarian" or affected by the particular social environment/ milieu within which the language learning process occurs. They can be found in monolingual versus bilingual contexts (Ellis, 1985).

Language attitude which differs in intensity or strength is an important concept as it plays a key role in language learning and teaching. Giving a broad definition of the concept "attitude", Wenden (1991) claimed that it contains three components; cognitive, affective, and behavioral. A cognitive component is made up of the beliefs, ideas, or opinions about the object of the attitude. The affective one refers to the feelings and emotions that one has towards an object, "likes" or "dislikes", "with" or "against". And finally, the behavioral component refers to one's behavioral intentions towards the object.

Since 1959 onwards, the progressive works by Gardner and Lambert have been de- 
pendable proofs that attitude has a great bearing on language learning. Since then, a plethora of research has been conducted in the study of attitudes in second/foreign language learning (e.g., Gardner, 1985, 2000, 2001; Gardner \& Lambert, 1959, 1972; Gardner, Smythe, \& Clément, 1979). Gardner and Lambert (1972, p. 3) whose major area of their investigation was done on attitude and its subsequent relation to L2 performance stated that "his (the learner) motivation to learn is thought to be determined by his attitudes towards the other group in particular and by his orientation towards the learning task itself".

Hsin and Clyde (1998) found that students could have either fear or unpleasant feelings about their past English learning experiences and also that students of different majors had different perspectives about English learning. Rani (2000) noted that students' attitudes towards learning might be developed through suggesting projects which give students experience in problem solving, and by proposing problems that require the collection of evidence for forming conclusions. Al-Quyadi (2000) inspected Sana'a University English majors' attitudes towards learning English and the results showed that the students had positive attitudes towards the English language and the use of English in the Yemeni social and educational contexts.

Most researchers agree that "a positive attitude towards a second language and its community helps second language learning" (De Bot, Lowie, \& Verspoor, 2005: p. 72). Nevertheless, Karahan's (2007) study indicated that most of Turkish EFL students could not attain the desired level of proficiency in English. Although the students were frequently exposed to English in a school environment, they, especially female students, had mildly positive attitudes, but interestingly, they did not reveal high-level orientation towards learning the language. In contrast, most of the Iranian studies; for example, Vaezi (2008) indicated that Iranian students had positive attitudes towards learning English.

Furthermore, Momani (2009) investigated Jordan's secondary stage students' attitudes towards learning English as a foreign language and their achievements in reading comprehension, and the findings showed that the respondents had neutral positive attitudes towards learning English, and that there was a strong correlation between the students' attitudes towards learning English and their performance in reading comprehension.

Chalak and Kassaian (2010) conducted another study with 108 English translation major students of Iran. The findings of their investigation on the students' motivational orientation and their attitude towards learning English showed that these EFL learners tended to learn English for both instrumental and integrative reasons, and that their attitude towards the target language was generally highly positive in nature.

Latif et al. (2011) directed a massive research with 757 learners nationwide to assess how several factors like motivation, attitude, anxiety, and instrumental orientation played role in influencing learners' performance in English language course in Open University Malaysia. Their study showed that the above factors were correlated with learners' performance, and that while personal motivation played an insignificant impact, attitude played a positive impact on performance in the English course conducted 
in there.

Al Mamun et al. (2012) conducted a questionnaire survey with 79 randomly selected non-major English undergraduate students of Bangladesh to gauge their attitude towards EFL. The research findings indicated that the learners had got a positive attitude towards English language, and that their motivational orientation was instrumental in nature. Moreover, Yang (2012) conducted a short study with 20 University Malaya Master students to gauge their attitudes and motivation in L2 and to find out what makes some people acquire and learn English better than others. The findings revealed that learners who were highly and positively involved in their English proficiency had positive attitudes and highly motivated towards learning English. However, Ahmed, Yossatorn and Yossiri (2012) investigated the students' attitudes towards activities used in an EFL classroom in one Thai university and found that more than half of the participants regarded their teacher's use of activities to determine their success in language learning, but less than half of them showed dissatisfaction with the EFL teacher using humor about their cultures as the part of his teaching. Further, Ibnian (2012) examined the effect of using the group work technique to develop the attitudes of non-English major students at the World Islamic Sciences and Education University (WISE) towards learning EFL. The results revealed the significant positive effect of using the group work technique on developing the attitudes of students towards leaning EFL. Another study conducted by Bobkina and Fernandez (2012) investigated the motivational patterns and attitudes towards the use of English in social and educational contexts of 72 EFL engineering students in Madrid. They found that the predominant motivation among Spanish engineering students was extrinsic in nature and most of the students had positive attitudes towards the social values and educational status of English, and that they had positive orientation towards the English language.

Alkaff (2013) conducted a study to explore the attitudes and perceptions of Foundation Year (FY) students towards learning English in Jeddah, Saudi Arabia. The study showed that most of the students had a positive attitude towards learning English, and that they tried to improve their English knowledge and use. Another study by Tahaineh and Daana (2013) investigated the motivation orientations of the Jordanian EFL female undergraduates and their attitudes towards learning the target language and its community. The findings showed the subjects' greater support of instrumental reasons for learning English language, including utilitarian and academic reasons. However, regarding the integrative reasons, the results provided evidence that learning English as a part of the culture of its people had the least impact in students' English language motivation; whereas, their attitudes towards the target language community and its members were generally found to be highly positive. Additionally, Tahaineh and Danna (2013) mentioned that attitudes play an eminent role in determining one's behavior, as the attitude has an impetus which stimulates the behavior and directs it in a particular direction, and that attitudes are thus indirectly related to L2 achievement; therefore, improving the positive attitude of the students towards a particular academic subject may increase their desire to learn the subject. 
Goktepe (2014) examined 90 first-year business studies undergraduates at a Turkish university and their attitude and motivation towards learning EFL, and the results showed that these learners learned English mostly for instrumental reasons, and that integrative motivation was dominant motivational orientation for the learners in some degree.

Al Samadani and Ibnian's (2015) study aimed to explore the attitudes of Umm Al-Qura University students towards learning EFL and the relationship between the students' attitudes and their grade point average (GPA). The results of their study showed that the students had overall positive attitudes towards learning EFL, and that students with high GPAs had the highest positive attitudes towards learning English. Further, Ahmed's (2015) study analyzed the result of a survey on 238 undergraduate EFL students in Malaysia, focusing on students' attitude towards English learning and causes that might have hindered their learning. The results of the qualitative analysis showed that the attitude towards English language learning and using the language in various domains of usage was extremely positive, but that most of the students had negative feelings or fear regarding classroom instructions in their learning experience. Also, students of different fields varied in attitudes towards English language learning in terms of domains of usage and focus of learning skills, which showed that a single curriculum or teaching methodology was not adequate.

\section{Aim of the Study}

Having reviewed a number of studies related to the purpose of the current study, the researchers of this current study observed that regarding the use of oral communication strategies, most of the previous studies have been conducted to investigate the various aspects of communication strategies and their relationship with language proficiency, task types, pronunciation difficulties, and critical thinking; however, their correlation with learners' attitudes towards learning EFL with a consideration of their English oral language output has rarely been under examination yet. Hence, to compensate for this gap specially in EFL context, which is in fact the novelty of the present research project, the study aimed at exploring the relationship among the three variables; speaking strategies use, attitude, and English language oral output of EFL learners. To do this, the three major research questions were formulated to seek the above-mentioned relationships. The research questions of the study posed are as follows:

(1) Is there any statistically significant relationship between speaking strategy use of the intermediate Iranian EFL learners and their attitude towards EFL learning?

(2) Is there any statistically significant relationship between speaking strategy use of the intermediate Iranian EFL learners and their English language oral output?

(3) Is there any statistically significant relationship between the intermediate Iranian EFL learners' attitude towards EFL learning and their English language oral output?

\section{Methodology}

\subsection{Participants}

A homogeneous sample of 150 female EFL learners, aged 13 - 18, enrolled in a private 
language institute in Kerman province, where one of the researchers had taught English for six years, was investigated using their oral output scores obtained on the Cambridge Preliminary English Test (PET). All of the participants were school students who had been studying Touchstone English language textbook series for about six terms. Each term consisted of twenty one-and-a-half-hour sessions.

\subsection{Instrumentation}

To obtain the required data for the present study, the following instruments were used:

1. Oral Communication Strategy Inventory (OCSI) designed by Nakatani (2006).

2. Attitude scale adapted by Rastegar (2003).

3. Cambridge Preliminary English Test (PET), placement tool for language proficiency.

Oral communication strategy questionnaire which was mainly based on the Oral Communication Strategy Inventory (OCSI) designed by Nakatani (2006) was administered. The questionnaire consists of 32 items of 8 categories for coping with speaking problems on a five-point scale, ranging from "never" to "always". According to Nakatani (2006), the reliability of 32 items was. 86 with acceptable internal consistency. The participants were asked to circle the response which indicated how often they used the strategy described.

Moreover, the twenty-item attitude scale adapted by Rastegar (2003) which is in Likert scale format, meant to assess the attitude of the participants, regarding a number of attitude objects in relation to learning English as a Foreign Language was applied. The scores range was from 20 to 100 . Obtaining high scores implies more favor and positive attitude towards L2 learning. Eight items (3, 4, 7, 10, 12, 14, 17, and 19) are reversely scored. The reliability indexes of the scale estimated by the author are favorably high--alpha $=0.80$ and $r=0.85$ (as cited in Rastegar, 2003). So, the attitude scale is a reliable measure for assessing the attitude of the EFL learners. The participants were required to indicate the degree of their agreement with each of the statements using the five-point scale; Strongly Agree, Agree, No Opinion, Disagree, and Strongly Disagree.

To shape homogeneous participants, the first task that participants were asked to carry out was a PET. This test is the main placement tool for all the intermediate learners. PET measures the English language proficiency of applicants. It generally addresses four language skills; Reading test, Writing test, Listening test, and Speaking test. Each part included authentic and real-world materials.

\subsection{Data Collection Procedure}

The study took place at Parsian English language institute, which is located in Bardsir; a small city near Kerman. It was important to document the homogeneity of the participants in terms of their language proficiency before the initiation of the study. Therefore, the PET was administered for the sake of homogenizing the subjects prior to the treatment at the beginning of the study. To select the target participants, the speaking section of the PET, which was very crucial in the future performances of the partici- 
pants, was considered whose validation was already ensured using the whole PET as a valid criterion. The students were aware that this task was a part of the research experiment, but not aware of the research questions.

The participants were asked to perform the four parts of the Speaking section individually. In part I, the Speaking test consisted of a general conversation, asking each candidate questions about the personal details, daily life, likes and dislikes, etc. In part II, the researcher described a situation and the participant was required to explain which pictures on the page were appropriate for that situation. In part III, the researcher asked each participant to describe a photo of people and finally in the last part, the researcher wanted the participant to talk about the things she enjoyed doing and the different times of the year she liked doing them. Each part of the Speaking test took 3 minutes to get completed.

After the administration of the PET, the two questionnaires were applied. The participants were informed that the study was designed to obtain empirical information about the strategies they adopted for the EFL speaking task and also about their attitude towards the EFL learning.

\section{Data Analysis and Results of the Study}

In the present study, a quantitative method in data analysis was used. There were three parts in the data analysis of this study; the PET and the two questionnaires. The score obtained on the speaking section of the PET was considered as the learners' score of their oral language output. For the scoring of the questionnaires, the scale range for each item was 1 - 5. Statistics of correlation test between the use of learners' speaking strategies and their attitudes towards language learning were done. Regression analysis to predict learners' PET scores through the speaking strategies as well as regression coefficients of the learners' speaking strategies with their PET scores were carried out. Statistics of correlation test between learners' attitudes towards language learning and their PET scores was conducted, too. The analyses are organized around relevant research questions. The results are presented in the following section.

\subsection{Analysis of RQ 1}

To answer RQ1 "Is there any statistically significant relationship between speaking strategy use of the intermediate Iranian EFL learners and their attitude towards EFL learning?" Pearson Correlation was run utilizing SPSS, the results of which are presented in Table 1. The correlations of the subscales of the learners' speaking strategies use and their attitude are present Table 1.

As can be seen in Table 1, the correlation coefficient between learners' attitudes towards language learning with social-affective strategies is $(r=0.253, p=0.077)$, the correlation coefficient between the attitudes of learners towards language learning with the fluency-oriented strategies $(r=0.433, p=0.002)$, the correlation coefficient between learners' attitudes towards language learning with strategies of negotiation for meaning while speaking $(r=0.384, p=0.006)$, the correlation coefficient between learners' 
Table 1. The learners' speaking strategies use and their attitudes.

\begin{tabular}{cccc}
\hline Speaking Strategies & Pearson Correlation & Sig. (2-tailed) & N \\
\hline Social-Affective Strategies & 0.253 & 0.077 & 150 \\
Fluency-Oriented Strategies & $0.433^{*}$ & 0.002 & 150 \\
Negotiation for Meaning While Speaking & $0.384^{*}$ & 0.006 & 150 \\
Accuracy-Oriented Strategies & $0.388^{*}$ & 0.005 & 150 \\
Message Reduction and Alteration Strategies & -0.198 & 0.168 & 150 \\
Nonverbal Strategies While Speaking & $-0.396^{*}$ & 0.004 & 150 \\
Message Abandonment Strategies & $-0.519^{*}$ & 0.001 & 150 \\
Attempt to Think in English Strategies & 0.18 & 0.212 & 150 \\
\hline
\end{tabular}

${ }^{\star}$ Correlation is significant at the 0.5 level ( 2 tailed).

attitudes towards language learning and accuracy-oriented strategies $(\mathrm{r}=0.388, p=$ 0.005), the correlation coefficient between learners' attitudes towards language learning with message reduction and alteration strategies $(\mathrm{r}=-0.198, p=0.168)$, the correlation coefficient between learners' attitude towards language learning and nonverbal strategies while speaking $(\mathrm{r}=-0.396, p=0.004)$, the correlation coefficient between learners "attitudes towards language learning with message abandonment strategies $(\mathrm{r}=-0.519$, $p=0.001)$, the correlation coefficient between learners" attitudes towards language learning and attempt to think in English strategies $(r=0.18, p=0.212)$.

Given the above information, therefore, at this level, the correlation between learners' attitudes towards language learning and Social-Affective Strategies, Fluency-oriented strategies, Negotiation for meaning while speaking Strategies, and Accuracy-oriented strategies, are positive and statistically significant.

However, as can be seen in Table 1, the results indicate that the learners' attitudes towards language learning does not have a significant correlation with Social-affective strategies, Message reduction and alteration strategies, and Attempt to think in English strategies.

On the other hand, as can be seen in Table 1 there is negative and statistically significant correlation between learners' attitudes towards learning language with, Nonverbal strategies while speaking, and Message abandonment strategies. The relationships of these variables are reverse and other variables relationships are straight (Table 1).

\subsection{Analysis of RQ 2}

To answer RQ 2 "Is there any statistically significant relationship between speaking strategy use of the intermediate Iranian EFL learners and their English language oral output?" Regression ANOVA to predict learners' PET scores through the speaking strategies and Multivariate Correlation and Rate of Determination Coefficient was run utilizing SPSS, the results of which are presented in Tables 2-4.

Given that the $p$-value calculated from the test (0.049) is less than the significance level of $0.05,\left(\mathrm{H}_{0}\right)$ will be rejected at this level; and therefore, the linear regression model 
Table 2. Regression ANOVA to predict learners' PET scores.

\begin{tabular}{ccccccc}
\hline \multicolumn{6}{c}{ ANOVA $^{\mathrm{a}}$} \\
\hline & Model & Sum of Squares & df & Mean Square & F & Sig. \\
\hline \multirow{3}{*}{1} & Regression & 205.852 & 8 & 25.732 & 2.179 & $0.049^{\mathrm{b}}$ \\
& Residual & 484.148 & 141 & 11.808 & & \\
& Total & 690.000 & 149 & & & \\
\hline
\end{tabular}

Table 3. Multivariate correlation and rate of determination coefficient.

\begin{tabular}{cccccc}
\hline \multicolumn{5}{c}{ Model Summary $^{\mathrm{b}}$} \\
\hline Model & $\mathrm{R}$ & R Square & Adjusted R Square & Std. Error of the Estimate & Durbin-Watson \\
\hline 1 & $0.546^{\mathrm{a}}$ & 0.298 & 0.161 & 3.43635 & 1.809 \\
\hline
\end{tabular}

Table 4. Regression coefficients of the learners' speaking strategies with their PET scores.

\begin{tabular}{|c|c|c|c|c|c|}
\hline \multirow{3}{*}{ Model } & \multicolumn{3}{|c|}{ Coefficients $^{\mathrm{a}}$} & \multirow{3}{*}{$\mathrm{t}$} & \multirow{3}{*}{ Sig. } \\
\hline & \multicolumn{2}{|c|}{ Non-standardized Coefficients } & \multirow{2}{*}{$\begin{array}{c}\text { Standardized } \\
\text { Coefficients } \\
\text { Beta }\end{array}$} & & \\
\hline & B & Std. Error & & & \\
\hline (Constant) & 21.172 & 6.234 & & 3.396 & 0.002 \\
\hline $\begin{array}{c}\text { Social-Affective } \\
\text { Strategies }\end{array}$ & 0.024 & 0.117 & 0.037 & 0.207 & 0.837 \\
\hline $\begin{array}{c}\text { Fluency-Oriented } \\
\text { Strategies }\end{array}$ & 0.013 & 0.174 & 0.019 & 0.072 & 0.943 \\
\hline $\begin{array}{l}\text { Negotiation for } \\
\text { Meaning While } \\
\text { Speaking }\end{array}$ & 0.118 & 0.191 & 0.136 & 0.616 & 0.541 \\
\hline $\begin{array}{c}\text { Accuracy-Oriented } \\
\text { Strategies }\end{array}$ & -0.193 & 0.173 & -0.283 & -1.119 & 0.270 \\
\hline $\begin{array}{c}\text { Message Reduction } \\
\text { and Alteration } \\
\text { Strategies }\end{array}$ & -0.009 & 0.195 & -0.008 & -0.048 & 0.962 \\
\hline $\begin{array}{c}\text { Nonverbal Strategies } \\
\text { While Speaking } \\
\text { Message }\end{array}$ & 0.687 & 0.383 & 0.538 & 1.793 & 0.080 \\
\hline $\begin{array}{l}\text { Abandonment } \\
\text { Strategies }\end{array}$ & -0.668 & 0.252 & -0.971 & -2.647 & 0.011 \\
\hline $\begin{array}{l}\text { Attempt to Think in } \\
\text { English Strategies }\end{array}$ & 0.201 & 0.409 & 0.114 & 0.490 & 0.626 \\
\hline
\end{tabular}

${ }^{a}$ Dependent Variable: PET scores.

is significant which means that there is a significant linear relationship between the components of learners' speaking strategies (social-affective, fluency-oriented, negotiation for meaning while speaking, accuracy-oriented, message reduction and alteration, nonverbal, message abandonment, and attempt to think in English strategies) and their PET scores. Multiple correlation coefficient is $r=0.546$, which represents the amount of relationship between learners' speaking strategies and their PET scores and this rela- 
tionship is significant because the significance level equals to 0.049 and is smaller than the $\alpha=0 / 05$ level. Since the $\mathrm{R}_{\text {adj }}^{2}$ amount (the adjusted $\mathrm{R}^{2}$ ) equals to $161 / 0$, thus all the entered variables in this model 0.161 can determine the variance of the learners' PET scores (Table 2 \& Table 3 ).

As the above table shows, only significance level of message abandonment variable is smaller than 0.05 and the other variables are significantly higher than 0.05 ; thus, only the regression coefficient of learners' message abandonment strategy with their PET scores is significant. Message abandonment regression coefficient $(\beta=-0.971)$ indicates that each change unit in message abandonment $(-0.971)$ is equivalent to change unit (increase) in the learners' PET scores (0.252).

\subsection{Analysis of RQ 3}

To answer RQ 3 "Is there any statistically significant relationship between the intermediate Iranian EFL learners' attitude towards EFL learning and their English language oral output?" Pearson Correlation was run utilizing SPSS, the results of which are presented in Table 5.

Data analysis through the Pearson test showed that the correlation coefficient between the two variables of learners' attitudes towards language learning and their PET scores was equal to 0.441 with the significance of 0.001 that is smaller than the significance level of $\alpha=0 / 05$; therefore, at this level the it can be stated that there exists a significant relationship between learners' attitudes towards language learning and their PET scores (Table 5).

\section{Discussion}

This study was an attempt to investigate the relationship among EFL learners' speaking strategies use, attitude, and English language oral output. The findings of the study are discussed with a consideration of the available works of other researchers in the area.

Regarding the first research question, the results revealed that the tendency of learning English among the students was high indicating that they are eager to learn English as a foreign language. In this part, the most score belonged to the Attempt to Think in English Strategies showing that instead of thinking in mother tongue, it is better to think and imagine in English and then try to put the imaginations in the form of speech; this is one of the best ways to improve speaking which leads to the learners' success in English speaking classes. There are three strategies that gain negative score which the researcher guesses that the students prefer other strategies over them. This result is in line with Ellis' (1985) work which emphasized the prominence of the class environment as a social situation in which the positive attitude towards the use of the most efficient speaking strategies can be fostered. Furthermore, the results of the

Table 5. Statistics of correlation test between learners' attitude and their PET scores.

\begin{tabular}{cccc}
\hline Variable & Pearson Correlation & Sig. (2-tailed) & N \\
\hline PET score & 0.441 & 0.001 & 150 \\
\hline
\end{tabular}


current study are specially in line with those revealed through the previous studies (e.g., Gardner \& Lambert, 1972; Al-Quyadi, 2000; De Bot, Lowie, \& Verspoor, 2005; Bobkina \& Fernandez, 2012; Tahaineh \& Daana, 2013) which resulted in the emphasis on the prominent impact of positive attitude on motivation towards language learning because the students recognize the importance of English learning in their education resulting in their willingness towards learning this language. Hence, based on a lot of studies conducted on this area, the researchers have mostly agreed on the idea that positive attitude facilitates learning process. However, this general result is in contrast with Karahan's (2007) study which indicated that there was no significant impact on the students' attitudes towards English learning.

With regard to the relationship between the use of speaking strategies and the learners' PET scores, data analysis of the current study showed the learners' success in gaining high scores of English exams such as PET. With regards to the results of Nakatani's (2006) study which showed that high proficiency learners were more likely to use social-affective strategies, fluency-oriented strategies, and negotiation for meaning whilst speaking strategies; in contrast, low proficiency learners were more likely to use message abandonment strategies, and with a consideration of the findings by Poulisse and Schils (1989) who stated that the most advanced students used fewer compensatory strategies than did the least proficient ones, by Prapobratanakul and Kangkun (2011) who found paralinguistic strategies (such as gestures or facial expressions) to be most frequently used ones, and by Nakatani, Makki, and Bradley (2012) who found that elementary-level students frequently used the strategies which impededthe flow of their communication, but advanced students mostlyemployed strategies to maintain the flow of interaction, the researcher can conclude that learners are enthusiastic about using the most useful speaking strategies to learn language as the best which results in their best oral output. This result is somehow in contrast with Derwing and Rossiter's (2002) investigation on the perceptions of adult ESL learners in regards with their pronunciation difficulties and the use of strategies while facing with communication breakdown which revealed that the most commonly used strategies were paraphrasing, self-repetition, writing/spelling, and volume adjustment when the participants had not been understood.

The answer to the third research question revealed that the learners' attitudes towards language learning and their PET scores are positively correlated. It means that most of the learners gain high scores on the PET or at least they pass the exam, so we understand that Iranian students have a positive attitude towards learning English and are a lot eager to pass English exams to get certifications and to be successful in their oral performances which is in line with the findings revealed through the investigations conducted by (e.g., Alkaff, 2013; Al Mamun et al., 2012; Al Samadani \& Ibnian, 2015; Chalak \& Kassaian, 2010; Latif et al., 2011; Momani, 2009; Vaezi, 2008).

\section{Conclusions}

Based on the results of the present examination, the language learners attempt to foster the viewpoint that thinking and speaking in English would help improve their oral 
communication skill. Therefore, the language teachers must provide the learners with the efficient and useful oral simulated real-life tasks and practices interwoven with strategy training within the EFL context in order to encourage them to think in English prior to making conversations rather than think in their mother tongue which leads to some communication breakdowns influenced by the significant differences between the two languages. The English language learners, aged 13 - 18, are so willing to communicate with their teacher and the peers using the speaking strategies taught in the classroom to develop their oral language output; thus, the EFL teachers must assist them in developing the speaking strategies by getting them exposed to as many best and helpful strategies as possible.

Among all the affective factors, attitude seems to be seen as the most indispensable concept in social psychology. It plays a crucial role in determining one's behavior since it has an impetus act which stimulates the behavior and directs it in a particular direction. It has a somewhat indirect relation to the language achievement. Improving the positive attitude of the students towards a particular academic subject may increase their desire to learn it and an ability to apply what they have been taught. This study also implicates that the high scores obtained on the PET are the indicative of the learners' high positive attitude towards learning English. According to Ellis (1985), the EFL teachers should foster a high positive attitude in the learners by paying a lot of attention to the way the learners find their way throughout learning the language and should provide the lively and dynamic class environments where can help students learn the language as best through the creation of a positive attitude towards the language being learnt and towards the environments in which it can be learnt. From what have been said, being aware of the importance of students' attitudes might help EFL curriculum and instruction designers to invent language teaching programs that generate the positive attitudes which lead to having more successful EFL learners (Gardner \& Lambert, 1972). Additionally, it can assist material writers in inventing and instructors in picking up tasks that tackle students' attitudes (Midraj, O'Neill, \& Sellami, 2008).

However, in Iran, where English is instructed as a foreign language, it is required for the learners to gain language competence as well as strategic competence to achieve autonomous language learning and language oral skills. Therefore, the importance of speaking strategy training in learner education with a regard to the learners' attitude towards language learning and their oral language output should not be ignored.

\section{References}

Ahmed, C. M. et al. (2012). Students' Attitudes towards Teachers' Using Activities in EFL class. International Journal of Academic Research in Business and Social Sciences, 2, 158-164.

Ahmed, Sh. (2015). Attitudes towards English Language Learning among EFL Learners at UMSKAL. Journal of Education and Practice, 6, 1-12. www.iiste.org

Al Mamun, Sk. A. et al. (2012). Students' Attitudes towards English: The Case of Life Science School of Khulna University. International Review of Social Sciences and Humanities, 3, 200-209.

http://irssh.com/yahoo_site_admin/assets/docs/20_IRSSH-264-V3N1.131231435.pdf 
Al Samadani, H. A., \& Ibnian, S. S. (2015). The Relationship between Saudi EFL Students' Attitudes towards Learning English and Their Academic Achievement. International Journal of Education and Social Science, 2, 92-102. http://www.ijessnet.com/wpcontent/uploads/2015/01/11.pdf

Alkaff, A. A. (2013). Students' Attitudes and Perceptions towards Learning English. Arab World English Journal AWEJ, 4, 106-121.

Al-Quyadi, A. (2000). Psycho-Sociological Variables in the Learning of English in Yemen. Ph. D Thesis, Bihar: Bhagalpur University.

Baker, C. (1992). Attitudes and Language. Clevedon: Multilingual Matters.

Baker, C. (2001). Foundations of Bilingual Education and Bilingualism (3rd ed.). Clevendon: Multilingual Matters LTD.

Bobkina, J., \& Fernandez de, M. C. D. (2012). Motivation and Attitudes towards Learning English: A Study of Engineering Undergraduates at the Technical University of Madrid. ICERI2012 Proceedings, 4492-4501. http://library.iated.org/view/BOBKINA2012MOT

Brown, H. D. (2000). Principles of Language Learning and Teaching (4th ed.). White Plains, NY: Pearson Education.

Canale, M. (1983). From Communicative Competence to Communicative Language Pedagogy. In J. C. Richard, \& R. W. Schmidt (Eds.), Language and Communication (pp. 2-14). London: Longman.

Canale, M., \& Swain, M. (1980). Theoretical Bases of Communicative Approaches to Second Language Teaching and Testing. Applied Linguistics, 1, 1-47. http://dx.doi.org/10.1093/applin/1.1.1

Chalak, A., \& Kassaian, Z. (2010). Motivation and Attitudes of Iranian Undergraduate EFL Students towards Learning English. GEMA Online Journal of Language Studies, 10, 37-56. http://ejournals.ukm.my/gema/article/view/108/99

Chuanchaisit, S., \& Prapphal, K. (2009). A Study of English Communication Strategies of Thai University Students. MANUSYA: Journal of Humanities, 17, 100-126.

Cohen, A. D. (1996). Second Language Learning and Use Strategies: Clarifying the Issues 1. Minnesota: Center for Advanced Research on Language Acquisition, University of Minnesota.

Corder, S. P. (1983). Strategies of Communication. In C. Faerch, \& G. Kasper (Eds.), Strategies in Interlanguage Communication. London: Longman.

De Bot, K., Lowie, W., \& Verspoor, M. (2005). Second Language Acquisition: An Advanced Resource Book. London: Routledge.

Derwing, T. M., \& Rossiter, M. J. (2002). ESL Learners' Perceptions of Their Pronunciation Needs and Strategies. System, 30, 155-166. http://dx.doi.org/10.1016/S0346-251X(02)00012-X

Dörnyei, Z. (1995). On the Teachability of Communication Strategies. TESOL Quarterly, 29, 55-85. http://dx.doi.org/10.2307/3587805

Dörnyei, Z., \& Scott, M. L. (1997). Communication Strategies in a Second Language: Definitions and Taxonomies. Language Learning, 47, 173-210. http://dx.doi.org/10.1111/0023-8333.51997005

Dörnyei, Z., \& Thurrell (1991). Strategic Competence and How to Teach It. ELT Journal, 45, 16-23. http://dx.doi.org/10.1093/elt/45.1.16

Ellis, R. (1985). Understanding Second Language Acquisition. Oxford: Oxford University Press.

Faerch, C., \& Kasper, G. (1983a). Strategies in Interlanguage Communication. London: Longman. 
Faerch, C., \& Kasper, G. (1983b). Plans and Strategies in Foreign Language Communication. In C. Faerch, \& G. Kasper (Eds.), Strategies in Interlanguage Communication (pp. 20-60). New York: Longman.

Fasold, R. (1984). The Sociolinguistics of Society. Oxford: Blackwell.

Gardner, R. C. (1985). Social Psychology and Language Learning: The Role of Attitude and Motivation. London: Edward Arnold.

Gardner, R. C. (2000). Correlation, Causation, Motivation and Second Language Acquisition. Canadian Psychology, 41, 10-24. http://dx.doi.org/10.1037/h0086854

Gardner, R. C. (2001). Integrative Motivation and Second Language Acquisition. In Z. Dörnyei, \& R. Schmidt (Eds.), Motivation and Second Language Acquisition, Honolulu: Publishing Company, Ltd.

Gardner, R. C. and Lambert, W. E. (1959). Motivational Variables in Second Language Acquisition. Canadian Journal of Psychology, 13, 266-272. http://dx.doi.org/10.1037/h0083787

Gardner, R. C., \& Lambert, W. E. (1972). Attitudes and Motivation in Second-Language Learning. Rowley, MA: Newbury House.

Gardner, R. C., Smythe, P. C., \& Clément, R. (1979). Intensive Second Language Study in a Bicultural Milieu: An Investigation of Attitudes, Motivation and Language Proficiency. Language Learning, 29, 305-320. http://dx.doi.org/10.1111/j.1467-1770.1979.tb01071.x

Gass, S. M., \& Selinker, L. (2001). Second Language Acquisition, an Introductory Course (2nd ed.). Mahwah, NJ: Lawrence Erlbaum Associates.

Goktepe, F. T. (2014). Attitudes and Motivation of Turkish Undergraduate EFL: Students towards Learning English Language. Studies in English Language Teaching, 2, 314-332. http://www.scholink.org/ojs/index.php/selt/article/view/239/219

Hosseini, S. E., Sarfallah, S., \& Bakhshipour, F. (2015). Exploring the Use of Oral Communication Strategies by Iranian EFL Critical Thinkers. International Journal of Language, Literature and Culture, 2, 6-12. http://www.openscienceonline.com/journal/ijllc

Ibnian, S. S. (2012). Group Work and Attitudes of Non-English Major Students towards Leaning EFL. International Journal of Humanities and Social Science, 2, 192-198.

Karahan, F. (2007). Language Attitudes of Turkish Students towards the English Language and Its Use in Turkish Context. Journal of Arts and Sciences Say, 7, 73-87.

Latif, L. A., Fadzil, M., Bahroom, R., Mohamad, W., \& Ng, M. S. (2011). The Role of Motivation, Attitude, Anxiety, and Instrumental Orientation in Influencing Learners' Performance in English as Second Language in OUM.

Littlemore, J. (2003). The Communicative Effectiveness of Different Types of Communication Strategy. System, 31, 331-347. http://dx.doi.org/10.1016/S0346-251X(03)00046-0

Mei, A., \& Nathalang, S. S. (2010). Use of Communication Strategies by Chinese EFL Learners. Chinese Journal of Applied Linguistics (Bimonthly), 33, 110-125.

Midraj, S., Midraj, J., O’Neill, G., \& Sellami, A. (2008). The Affective Factors and English Language Attainment of Arab EFL Learners. International Journal of Applied Educational Studies, 1, 43 .

Momani, M. (2009). The Jordanian Secondary Stage students Achievement in Reading Comprehension According to Their Views towards Learning English as a Foreign Language. Journal of Human Sciences, 42, 1-36.

Nakatani, Y. (2006). Developing an Oral Communication Strategy Inventory. Modern Language Journal, 90, 151-168.

Nakatani, Y., \& Gho, C. (2007). A Review of Oral Communication Strategies: Focus on Interac- 
tionist and Psycholinguistic Perspectives. In A. D. Cohen, \& E. Macro (Eds.), Language Learner Strategies (pp. 205-227). Oxford: Oxford University Press.

Nakatani, Y., Makki, M., \& Bradley, J. (2012). "Free” to Choose: Communication Strategy Use in EFL Classrooms in Iran. Iranian Journal of Applied Linguistics, 15, 61-83.

Paribakht, T. (1985). Strategic Competence and Language Proficiency. Applied Linguistics, 6, 132-146. http://dx.doi.org/10.1093/applin/6.2.132

Patil, S., \& Karekatti, T. (2015). The Use of Communication Strategies in Oral Communicative Situations by Engineering Students. Language in India, 15, 1-25.

www.languageinindia.com

Poulisse, N., \& Schils, E. (1989). The Influence of Task- and Proficiency-Related Factors on the Use of Compensatory Strategies: A Quantitative Analysis. Language Learning, 39, 15-46. http://dx.doi.org/10.1111/j.1467-1770.1989.tb00590.x

Prapobratanakul, C., \& Kangkun, P. (2011). Young ESL Learners' Strategic Competence: What Do Thai Fourth Graders Do to Enhance Communication? In Proceedings of the International Conference: Expanding Horizons in English Language and Literary Studies (pp. 114-124). Bangkok: Chulalongkorn University.

Rababah, G. (2003). Communication and Linguistic Problems Facing Arab Learners of English. Indian Journal of Applied Linguistics, 29, 127-42.

Rababah, G. (2005). Communication Problems Facing Arab Learners of English. Journal of Language and Learning, 3, 194.

Rani, K. (2000). Educational Aspirations and Scientific Attitudes. New Delhi: Discovery Publishing House.

Rastegar, M. (2003). A Handbook of Personality Scales for Research in Applied Linguistics. Iran, Kerman: Farhang Publications.

Rost, M., \& Ross, S. (1991). Learner Use of Strategies in Interaction: Typology and Teachability. Language Learning, 41, 235-268. http://dx.doi.org/10.1111/j.1467-1770.1991.tb00685.x

Selinker, L. (1972). Interlanguage. International Review of Applied Linguistics in Language Teaching, 10, 209-232. http://dx.doi.org/10.1515/iral.1972.10.1-4.209

Stern, H. H. (1983). Fundamental Concepts of Language Teaching. Oxford, England: Oxford University Press.

Tahaineh, Y., \& Daana, H. (2013). Jordanian Undergraduates' Motivations and Attitudes towards Learning English in EFL Context. International Review of Social Sciences and Humanities, 4, $159-180$

Tarone et al. (1976). A Closer Look at Some Interlanguage Terminology: A Framework for Communication Strategies. Working papers on Bilingualism, No. 9. Toronto, Canada. (ERIC Document Reproduction Service No. ED 125 313)

Tarone, E. (1980). Communication Strategies, Foreigner Talks, and Repair in Interlanguage. Language Learning, 30, 417-431. http://dx.doi.org/10.1111/j.1467-1770.1980.tb00326.x

Tarone, E. (1981). Some Thoughts on the Notion of Communication Strategy. TESOL Quarterly, 15, 285-295. http://dx.doi.org/10.2307/3586754

Vaezi, Z. (2008). Language Learning Motivation among Iranian Undergraduate Students. World Applied Sciences Journal, 5, 54-61.

Wannaruk, A. (2003). Communication Strategies Employed by EST Students. SLLT, 12, 1-18.

Wenden, A. (1991). Learner Strategies for Learner Autonomy. Englewood Cliffs, NJ: PrenticeHall. 
Yang, X. (2012). Attitude and Motivation in L2 Learning among UM Master Students. International Journal of Management and Sustainability, 1, 13-22.

Yarahmadzehi, N., \& Safarzade Samani, F. (2014). Communication Strategies Used by Iranian Pre-Intermediate EFL Learners in Oral Communication. Journal of Academic and Applied Sciences, 4, 13-27.

Yarmohammadi, L., \& Seif, S. (1992). More on Communication Strategies: Classification, Resources, Frequency and Underlying Processes. International Review of Applied Linguistics, 30, 223-232.

Zhang, W. (2005). The Selection of Communication Strategies by Taiwanese EFL Elementary School Students with Different English Proficiency Levels in Information-Gap Activities. Master Thesis, New Taipei: National Taipei University of Education.

Submit or recommend next manuscript to SCIRP and we will provide best service for you:

Accepting pre-submission inquiries through Email, Facebook, LinkedIn, Twitter, etc.

A wide selection of journals (inclusive of 9 subjects, more than 200 journals)

Providing 24-hour high-quality service

User-friendly online submission system

Fair and swift peer-review system

Efficient typesetting and proofreading procedure

Display of the result of downloads and visits, as well as the number of cited articles

Maximum dissemination of your research work

Submit your manuscript at: http://papersubmission.scirp.org/

Or contact ojml@scirp.org 